\title{
PURPLE CABBAGE MICROGREENS GROWN IN DIFFERENT SUBSTRATES AND NUTRITIVE SOLUTION CONCENTRATIONS ${ }^{1}$
}

\author{
ALBERTINA RADTKE WIETH ${ }^{2}$, WAGNER DUTRA PINHEIRO ${ }^{2}$, TATIANA DA SILVA DUARTE²
}

\begin{abstract}
Microgreens are young plants that are consumed at the seedling stage, which present short production cycle and require little space for growing. The objective of the present study was to evaluate the yield and nutritional quality of purple cabbage (Brassica oleracea var. capitata f. rubra) microgreens grown in different substrates and nutrient concentrations in the nutritive solution, in a recirculating irrigation system. The experiment was conducted in a protected environment at the Faculty of Agronomy (UFRGS), in Porto Alegre, RS, Brazil. A completely randomized design and three replications were used, with a $4 \times 3$ factorial arrangement consisted of four commercial substrates $\left(\mathrm{CSC}^{\circledR}\right.$ vermiculite, Beifiur ${ }^{\circledR} \mathrm{S} 10$, Carolina Soil ${ }^{\circledR}$ seedling, and Carolina Soil $^{\circledR}$ organic) and three nutrient concentrations in the nutritive solution $(0 \%, 50 \%$, and $100 \%)$. A sub-irrigation system was used for the irrigations. The variables evaluate were: shoot fresh matter yield (SFMY), shoot dry matter yield (SDMY), shoot height at harvest (SHH), production cycle (precocity), and total soluble solids (TSS), total chlorophyll, and carotenoid contents. The different substrates had no effect on the SFMY, SDMY, and $\mathrm{SHH}$ of the purple cabbage microgreens; the increasing addition of nutrients to the nutritive solution increased the values of these variables. The TSS and total carotenoid contents decreased as the nutrient concentration in the nutritive solution was increased. The responses of total chlorophyll contents to the substrates and the nutrient concentrations in the nutritive solution varied.
\end{abstract}

Keywords: Brassica oleracea var. capitata f. rubra. Microverdes. Dry matter yield.

\section{MICROGREENS DE REPOLHO ROXO CULTIVADO EM DIFERENTES SUBSTRATOS E CONCENTRAÇÕES DE SOLUÇÃO NUTRITIVA}

\begin{abstract}
RESUMO - Microgreens são vegetais jovens, consumidos ainda na fase de plântula, com ciclo curto de produção e necessidade de pequenos espaços para o seu cultivo. O presente estudo teve por objetivo avaliar a produtividade e a qualidade nutricional de microgreens de repolho roxo (Brassica oleracea var. capitata $f$. rubra) em diferentes substratos comerciais e concentrações de solução nutritiva, em sistema recirculante de irrigação. O experimento foi conduzido em ambiente protegido, no Campus da Faculdade de Agronomia (UFRGS), em Porto Alegre. Utilizou-se o delineamento inteiramente casualizado, com arranjo fatorial 4x3 com 3 repetições. Os tratamentos foram compostos pelas combinações de quatro substratos comerciais, vermiculita $\mathrm{CSC}^{\circledR}(\mathrm{S} 1)$, S10 Beifiur ${ }^{\circledR}$ (S2), Carolina Soil ${ }^{\circledR}$ mudas (S3) e Carolina Soil Orgânico ${ }^{\circledR}$ (S4) e três concentrações $(0,50$ e $100 \%)$ de nutrientes na solução nutritiva. As irrigações foram realizadas por sistema de subirrigação. Foram avaliadas a produtividade média de massa fresca (MF) e seca (MS) da parte aérea, altura de plântulas, duração de ciclo (precocidade) teor de sólidos solúveis (TSS), clorofilas e carotenoides totais. Os diferentes substratos não influenciaram sobre as variáveis de produtividade de MF e de MS da parte aérea e altura de microgreens de repolho roxo. A adição de nutrientes à solução nutritiva propicia o aumento destas mesmas variáveis. O teor de sólidos solúveis e o conteúdo total de carotenoides reduziu com o aumento da concentração da solução nutritiva. A resposta para o conteúdo total de clorofilas foi inconstante entre os substratos e as diferentes concentrações de nutrientes na solução nutritiva.
\end{abstract}

Keywords: Brassica oleracea var. capitata f. rubra. Microverdes. Rendimento de matéria seca.

\footnotetext{
${ }^{*}$ Corresponding author

${ }^{1}$ Received for publication in $05 / 31 / 2019$; accepted in 10/09/2019.

Paper extracted from the first author's Master's dissertation.

${ }^{2}$ Department of Horticulture and Forestry, Universidade Federal do Rio Grande do Sul, Porto Alegre, RS, Brazil; albertina.w@hotmail.com - ORCID: 0000-0002-4401-8603, wagner_dutra_pinheiro@hotmail.com - ORCID: 0000-0002-5293-3115, tatiana.duarte@ufrgs.br ORCID: 0000-0001-7240-0853.
} 


\section{INTRODUCTION}

Microgreen consumption is a potential mechanism to diversify food systems, especially urban, contributing to increase the resilience of the current society to climate changes. Microgreens are young plants that are consumed at the seedling stage, with heights of 5 to $10 \mathrm{~cm}$, and are produced from different vegetable, aromatic, and condiment species. They present a short production cycle, which can be two to three weeks depending on the species, require little space for growing (KOPSELL et al., 2012), and can be grown all year round and in several production cycles (SAMUOLIENE் et al., 2017). They are popular by their attractive colors, intense flavor, delicate textures, and high nutritional value (SAMUOLIENE et al., 2016). The harvest time is reached when the cotyledons are still turgid and before true leaves are completely expanded. Usually, only the aerial part of seedlings is consumed.

Microgreens are functional food because of their properties that contribute to the human health. Functional foods or plants with specific characteristics have increasingly drawing attention of the food market due to its increasing demand in the last years (JANOVSKÁ; STOCKOVÁ; STEHNO, 2010; SIRTAUTAS et al., 2012).

Among chemical properties of substrates for crop plants, the electrical conductivity (EC) and acidity $(\mathrm{pH})$ are important for plant growth and development. EC is directly related to soluble salt contents, which can affect the plants' biomass production, either at the seedling and adult stages. However, the plants' response to salt contents in the medium is dependent on the species; thus, these contents should be maintained at acceptable levels (KÄMPF; FERMINO, 2000) according to the species and phenological stage. Moreover, the $\mathrm{pH}$ of the substrate affects nutrient absorption by plants; microorganisms; and the root system development (KÄMPF; FERMINO, 2000).

There are no specific recommendations for producing microgreens or studies on the ideal range of $\mathrm{EC}$ and $\mathrm{pH}$ and their effects on the crop, especially when using nutritive solutions. Moreover, little studies show technics and managements that increase crop yield of microgreens. In this context, the objective of the present study was to evaluate the yield and nutritional quality of purple cabbage (Brassica oleracea var. capitata $f$. rubra) microgreens grown in different substrates and nutrient concentrations in the nutritive solution, using a recirculating irrigation system.

\section{MATERIAL AND METHODS}

The experiment was conducted at the Department of Horticulture and Silviculture of the
Faculty of Agronomy of the Federal University of Rio Grande of Sul (UFRGS), in Porto Alegre, RS, Brazil, in an east-west oriented environment protected by a plastic film cover and with dimensions of $5 \times 10 \mathrm{~m}$ and minimum height of 3.0 m.

Non-treated seeds of purple cabbage (Super Red cultivar; Isla Sementes ${ }^{\circledR}$ ) were manually sowed on September 11, 2018, at a density of $0.102 \mathrm{Kg} \mathrm{m}^{-2}$. The substrates were placed in white polystyrene trays of $0.14 \times 0.21 \mathrm{~m}$ with depth of $0.015 \mathrm{~m}$, without compartmentation, and perforated at the base. A layer of approximately $0.01 \mathrm{~m}$ of previously wetted substrate was placed in each tray, and the seeds were sowed on it; each tray was considered as an experimental unit. The trays were distributed in rectangular pools, which are the structures proposed for irrigation in this microgreen production system. These polls were made of wood covered with a double face film (black/white); they had depth of $0.07 \mathrm{~m}$ and slope of $2 \%$. After sowing, the trays were maintained in the dark during three days by covering them with paper sheets; they were uncovered when the seeds were already germinated. This technic was used to favor seed germination and the uniform growing of seedlings in the trays.

The experiment was conducted in a completely randomized design with three replications, using a $4 \times 3$ factorial arrangement consisted of four commercial substrates $\left(\mathrm{CSC}^{\circledR}\right.$ vermiculite - S1, Beifiur ${ }^{\circledR} \mathrm{S} 10-\mathrm{S} 2$, Carolina Soil ${ }^{\circledR}$ seedling - S3, and Carolina Soil ${ }^{\circledR}$ organic - S4) and three nutrient concentrations in the nutritive solution $(0,50$, and $100 \%)$, totaling 9 pools of four trays. The nutritive solution used was based on a solution recommended for hydroponic forage by Santos et al. (2004), which is composed of macronutrients (mmol $\left.\mathrm{L}^{-1}\right) 13.89$ of $\mathrm{NO}_{3}^{-}, 1.41$ of $\mathrm{H}_{2} \mathrm{PO}_{4}^{-}, 1.09$ of $\mathrm{SO}_{4}{ }^{2-}$, 1.41 of $\mathrm{NH}_{4}^{+}, 6.41$ of $\mathrm{K}^{+}, 3.4$ of $\mathrm{Ca}^{2+}$, and 1.09 of $\mathrm{Mg}^{2+}$ and micronutrients $\left(\mathrm{mg} \mathrm{L}^{-1}\right) 5.0$ of $\mathrm{Fe}, 0.05$ of $\mathrm{Mn}, 0.09$ of $\mathrm{Zn}, 0.10$ of $\mathrm{B}, 0.04$ of $\mathrm{Cu}$, and 0.02 of Mo. Rainwater was used to make the nutrient solution; its initial electrical conductivity $\left(\mathrm{EC}_{\mathrm{i}}\right)$ was 0 ( $0 \%$ nutrient concentration), $1.20 \quad(50 \%$ nutrient concentration), and $2.00 \mathrm{dS} \mathrm{m}^{-1}$ (100\% nutrient concentration), with $\mathrm{pH}$ values of 5.5 to 6.0 .

The substrates tested were sterilized in autoclave for 120 minutes at temperature of $120^{\circ} \mathrm{C}$ and pressure of $1.5 \mathrm{~atm}$; then, their chemical properties ( $\mathrm{pH}$ and electrical conductivity) and physical properties (wet and dry densities, total porosity, aeration space, readily available water, and water retention capacity) were evaluated in the Laboratory of Substrate Analysis of the UFRGS.

A sub-irrigation system was used, with intermittent supply (15 min hour $\left.{ }^{-1}\right)$ of nutritive solution from 8:00 a.m. to 6:00 p.m. plus two irrigations of 15 minutes during the nighttime. The pools had a drain for conduction of the solution to the recirculation tank, characterizing a closed system 
without solution loss.

The average air temperature and relative humidity were monitored daily during the experiment, using a datalogger (AK174; AKSO ${ }^{\circledR}$ ) installed in the crop environment near the production benches.

The harvest time was reached at 9 to 11 days after sowing, when $80 \%$ of the microgreens presented primary leaves at initial development. The microgreens were harvested by cuts at the base of the seedling, near the substrate, using scissors.

The productivity variables evaluated were: shoot fresh matter yield (SFMY), shoot dry matter yield (SDMY), and shoot height at harvest (SHH). The SHH was measured with a ruler from the stem base to the top of the seedling in four points of the tray.

The nutritional quality of the seedling was evaluated by assessing their total soluble solid (TTS) and chlorophyll and carotenoid contents. TSS content ( ${ }^{\circ}$ Brix) was determined in the liquid extracted by maceration of ten seedlings of each replication, using a digital refractometer (PAL-1 3810; Atago $^{\circledR}$ ). The total chlorophyll and carotenoid contents were determined in $80 \%$ acetone using ten seedlings of each replication, which were macerated with calcium carbonate $\left(\mathrm{CaCO}_{3}\right)$ and the resulting extract was filtered in filter paper, in 25-mL Kjeldahl flasks (ARNON, 1949); then, the material was immediately subjected to absorbance readings, using
647 to $663 \mathrm{~nm}$ for determination of chlorophylls, and $470 \mathrm{~nm}$ for carotenoids; their concentrations were calculated by the formula of Lichtenthaler (1987).

The results were subjected to analysis of variance by the $\mathrm{F}$ test and the means were compared by the Tukey's test at 5\% probability of error, using the Sisvar program (FERREIRA, 2011).

\section{RESULTS AND DISCUSSION}

The substrate Beifiur ${ }^{\circledR}$ S10 (S2) presented the highest electrical conductivity (EC) (mean of 1.20 $\mathrm{dS} \mathrm{m}^{-1}$ ); the EC of the other substrates varied from 0.01 to $0.46 \mathrm{dS} \mathrm{m}^{-1}$. (Table 1). EC values lower than $0.65 \mathrm{dS} \mathrm{m}^{-1}$ are adequate for materials used as substrates (CAVINS et al., 2000). Thus, the substrate $\mathrm{S} 10$ Beifiur ${ }^{\circledR}$ was the only one that present $\mathrm{EC}$ above that recommended.

The means of $\mathrm{pH}$ of the substrates were between 4.86 for $\mathrm{S} 2$ and 6.34 for $\mathrm{CSC}^{\circledR}$ vermiculite (S1). According to Kämpf and Fermino (2000), the ideal $\mathrm{pH}$ for substrates with predominance of organic matter used to produce seedlings is between 5.0 and $5.8 ; \mathrm{pH}$ above or below this range can compromise physiological activities that are important for germination and rooting (GRUSZYNSKI, 2002). These situations were not found in the present study, since the substrates that had $\mathrm{pH}$ above this ideal range presented values very close to this range.

Table 1. Chemical and physical characterization of commercial substrates used in the production of purple cabbage microgreens (Brassica oleracea var. capitata f. rubra). $\mathrm{CSC}^{\circledR}$ Vermiculite (S1), Beifiur ${ }^{\circledR} \mathrm{S} 10(\mathrm{~S} 2)$, Carolina Soil ${ }^{\circledR}$ seedlings (S3) and Carolina Soil Organic ${ }^{\circledR}$ (S4). Porto Alegre, Brazil, UFRGS. 2018.

\begin{tabular}{lcccc}
\hline \multirow{2}{*}{ Chemical characteristics } & \multicolumn{4}{c}{ Substrates } \\
\cline { 2 - 5 } & $\mathrm{S} 1$ & $\mathrm{~S} 2$ & $\mathrm{~S} 3$ & $\mathrm{~S} 4$ \\
\hline $\mathrm{EC}\left(\mathrm{dS} \mathrm{m}^{-1}\right)$ & 0.01 & 1.20 & 0.46 & 0.28 \\
$\mathrm{pH}\left(\mathrm{H}_{2} \mathrm{O}\right)$ & 6.34 & 4.86 & 5.26 & 5.98 \\
\hline Physical characteristics & & & & \\
\hline Wet density $\left(\mathrm{kg} \mathrm{m}^{-3}\right)$ & 181.36 & 582.85 & 262.57 & 313.58 \\
Dry density $\left(\mathrm{kg} \mathrm{m}^{-3}\right)$ & 177.90 & 302.74 & 122.41 & 113.44 \\
TP \% & 73.23 & 81.33 & 87.73 & 91.62 \\
AS \% & 23.24 & 21.48 & 38.91 & 29.32 \\
RAW \% & 7.21 & 15.50 & 13.07 & 21.48 \\
WRC-10 \% & 49.99 & 59.84 & 48.82 & 62.63 \\
\hline
\end{tabular}

$\mathrm{EC}=$ electrical conductivity in a 1:5 solution $\left(\mathrm{v} \mathrm{v}^{-1}\right) ; \mathrm{pH}=$ in $\mathrm{H}_{2} \mathrm{O}$, dilution of 1:5 $\left(\mathrm{v} \mathrm{v}^{-1}\right)$; $\mathrm{TP}=$ total porosity; $\mathrm{AS}=$ aeration space; RAW $=$ readily available water; $\mathrm{WRC}-10=$ water retention capacity under suction of a $10 \mathrm{~cm}$ water column, determined in volumetric basis $\left(\mathrm{v} \mathrm{v}^{-1}\right)$.

The substrate density expresses the relation between its weight and volume; in general, the dry density is used as an evaluation parameter, since the wet density varies according to the amount of water in the material (SCHÄFER et al., 2015). The higher the density, the more difficult is the growing of seedlings in trays, for which the ideal value is between 100 to $300 \mathrm{~kg} \mathrm{~m}^{-3}$ (KÄMPF; FERMINO 2000). The substrate S2 (S10Beifiur $\left.{ }^{\circledR}\right)$ had dry density close to the recommended one and had higher wet density than the other substrates (Table 1). This generated a resistance to penetration of roots in the substrate, hindering the establishment of seedlings, as observed visually during the experiment. Thus, increases in the substrate density decrease the porosity and change the relationship between substrate and roots, limiting the root growth 
(FERREIRA et al., 2010).

The recommended total porosity in the literature is $85 \%(80-90 \%)$ (BOODT; VERDONCK, 1971; KÄMPF, 2005). Among the substrates evaluated, only $\mathrm{S} 1$ presented results outside this range, although with values close to this ideal range. The aeration spaces of the substrates S1, S2, and Carolina Soil ${ }^{\circledR}$ organic (S4), were within the reference values found in the literature $-20 \%$ to $30 \%$ of the volume (BOODT; VERDONCK, 1971); only the Carolina Soil ${ }^{\circledR}$ seedling (S3) (Table 1) presented values above this range. However, the higher aeration space in this substrate did not cause losses in the microgreen yields. Similar results were found by Klein et al. (2012) for lettuce seedlings when using substrates with mean aeration space of $13 \%$ above the range found in the literature, without losses in production.

The interaction between the factors (substrate and nutrient concentration in the nutritive solution) was not significant for shoot fresh matter yield (SFMY), shoot dry matter yield (SDMY), shoot height at harvest $(\mathrm{SHH})$, and total soluble solids (TSS) content (Table 2). Thus, the results were interpreted separately for each factor.

Table 2. Effect of cultivation substrate and nutrient solution concentration on shoot fresh matter yield (SFMY) and shoot dry matter yield (SDMY), shoot height at harvest (SHH), and total soluble solids (TSS) content of purple cabbage microgreens (Brassica oleracea var. capitata f. rubra) in a recirculating system. Porto Alegre, Brazil, 2018.

\begin{tabular}{|c|c|c|c|c|c|}
\hline \multirow{2}{*}{ Factors } & \multirow{2}{*}{ Trataments } & SFMY & SDMY & \multirow{2}{*}{$\mathrm{SHH}(\mathrm{cm})$} & \multirow{2}{*}{$\begin{array}{c}\text { TSS } \\
\text { ('brix) }\end{array}$} \\
\hline & & \multicolumn{2}{|c|}{$\left(\mathrm{g} \mathrm{m}^{-2}\right)$} & & \\
\hline \multirow{4}{*}{ Substratos } & S1 $\left(\operatorname{CSC}^{\circledR}\right.$ Vermiculite $)$ & $1829.52^{\mathrm{ns}}$ & $74.01^{\mathrm{ns}}$ & $6.86^{\mathrm{ns}}$ & $3.62^{\mathrm{ns}}$ \\
\hline & $\mathrm{S} 2\left(\right.$ Beifiur $\left.^{\mathbb{B}} \mathrm{S} 10\right)$ & 1761.30 & 79.21 & 6.89 & 3.64 \\
\hline & S3 (Carolina Soil ${ }^{\circledR}$ seedling) & 1795.73 & 75.70 & 6.83 & 3.73 \\
\hline & S4 (Carolina Soil $^{\circledR}$ organic) & 1793.57 & 81.10 & 7.19 & 3.82 \\
\hline \multirow{5}{*}{ Concentration Nutritive Solution ** } & $\mathrm{C} 1(0 \%)$ & $1111.31 \mathrm{c}^{*}$ & $64.34 \mathrm{c}$ & $5.00 \mathrm{c}$ & $5.03 \mathrm{a}$ \\
\hline & $\mathrm{C} 2(50 \%)$ & $1933.16 \mathrm{~b}$ & $78.62 \mathrm{~b}$ & $7.36 \mathrm{~b}$ & $3.37 \mathrm{~b}$ \\
\hline & C3 $(100 \%)$ & $2340.62 \mathrm{a}$ & $89.59 \mathrm{a}$ & $8.48 \mathrm{a}$ & $2.72 \mathrm{c}$ \\
\hline & Mean & 1795.03 & 77.52 & 6.94 & 3.70 \\
\hline & $\mathrm{CV}(\%)$ & 16.34 & 11.29 & 6.83 & 14.45 \\
\hline
\end{tabular}

${ }^{\mathrm{n} s}$ not significant by the Tukey's test at $5 \%$ probability; * means followed by the same letter in the columns are not different by the Tukey's test at $5 \%$ probability. ${ }^{* *}$ initial electrical conductivity (ECi) established for the three evaluated nutrient concentrations $(0 \%, 50 \%$, and $100 \%)$ in the nutritive solution: $\mathrm{C} 1=0.0 ; \mathrm{C} 2=1.20$, and $\mathrm{C} 3=$ $2.0 \mathrm{dS} \mathrm{m}^{-1}$, respectively.

The substrates had no significant effect on the SFMY, SDMY, SHH, and total soluble solids (TSS) content. However, the nutrient concentration in the nutritive solution had significant effect on these variables (Table 2).

The addition of nutrients to the irrigation water increased the mean SFMY in $110 \%$ for the nutrient concentration of $100 \%(\mathrm{C} 3)$, regardless the substrate used (Table 2). SFMY is an important commercial factor since the product is sold by its fresh weight. Thus, the purple cabbage microgreen production responded positively to the use of nutritive solution, with increases in production of $74 \%$ when using the nutrient concentration of $50 \%$ (C2), and $21 \%$ when using $\mathrm{C} 3$ compared to $\mathrm{C} 2$.

The highest SFMY found for the purple cabbage microgreen plants evaluated was $2.340 \mathrm{~g} \mathrm{~m}^{-2}$ (Table 2). Bulgari et al. (2017) evaluated vegetable microgreens (Ocimum basilicum L., and Beta vulgaris L. subsp. vulgaris) in floating system, using vermiculite as substrate and a nutrient concentration of $50 \%$ in the nutritive solution, and found similar results, with mean variation of 1,100 to $1,900 \mathrm{~g} \mathrm{~m}^{-2}$; the EC of the nutritive solution that they used was $1.12 \mathrm{dS} \mathrm{m}^{-1}$, which was similar to the ECi $\left(1.2 \mathrm{dS} \mathrm{m}^{-1}\right)$ used in the present study for $\mathrm{C} 2$.

The addition of nutrients to the irrigation water $(\mathrm{C} 2$ and $\mathrm{C} 3)$ resulted in increases in SDMY and SHH (Table 2), which are similar results to those found for SFMY. The SDMY, evaluated as a percentage of the fresh weight, varied from $3.83 \%$ (C3) to $5.78 \%(\mathrm{C} 1)$. These values were lower than those found by Xiao et al. (2016) (7.7 \%) for 25 different commercial microgreen species, including purple cabbage.

TSS content was 46\% lower when using C3 than when using $\mathrm{C} 1$ (Table 2), which is an inverse result compared to those for SFMY, SDMY, and SHH. The TSS represent the sugars and acids in the plant material. According to some studies, the higher the TSS, the better the flavor and aroma; thus, it is an important factor for consumers of fresh foods (SOBREIRA et al., 2010; MACIEL et al., 2015) such as microgreens, whose attractive characteristics 
are flavor and visual appearance. Therefore, this is a parameter of evaluation for microgreens, since different production systems, substrates, and nutrient supply can result in products that will provide different experiences to the consumer.

The analysis of variance by the $F$ test indicated a significant interaction $(<0.05)$ between the factors (substrate and nutrient concentration in the nutritive solution) for the variables production cycle (Table 3 ) and total chlorophyll and carotenoid contents (Figures 3 and 4).
The production cycle (Table 3) decreased with the addition of nutrients (at concentration of $100 \%$ ) to the nutritive solution, decreasing the harvest time in 2 days when using the substrates S1 and S2. However, the addition of nutrients in the nutritive solution did not affect this variable when using the substrates S3 and S4. Thus, considering only the obtaining of precocious plants, no additional costs with fertilizers and management of the nutritive solution are necessary for these substrates.

Table 3. Effect of commercial substrates and nutrient concentration in the nutrient solution, $0 \%(\mathrm{C} 1), 50 \%(\mathrm{C} 2)$ and $100 \%$ (C3), on cycle duration (days) of purple cabbage (Brassica oleracea var. capitata f. rubra) microgreens production in recirculating system. Porto Alegre, Brazil, 2018.

\begin{tabular}{lccc}
\hline \multicolumn{4}{c}{ CYCLE (days) } \\
\hline
\end{tabular}

The total chlorophyll content varies according to the substrate used within the nutrient concentrations in the nutritive solution (Figure 1), presenting 0.256 to $0.456 \mathrm{mg} \mathrm{g}^{-1-}$ of fresh matter. Chlorophylls are an important parameter for quality evaluation of fresh products; they are perceived in the quality aspects of the product (SOARES et al., 2016; BULGARI et al., 2017).

The plants treated with $\mathrm{C} 1 \quad(0 \%$ nutrient concentration) presented the lowest differences in total chlorophyll contents within the substrates used (Figure 1), with 0.439 to $0.363 \mathrm{mg} \mathrm{g}^{-1}$ of fresh matter. The highest total chlorophyll contents were found using the substrate S1 with $\mathrm{C} 2\left(0.456 \mathrm{mg} \mathrm{g}^{-1}\right.$ of fresh matter) and $\mathrm{C} 3\left(0.435 \mathrm{mg} \mathrm{g}^{-1}\right.$ of fresh matter), the substrate S2 with $\mathrm{C} 1\left(0.439 \mathrm{mg} \mathrm{g}^{-1}\right.$ of fresh matter), and the substrate S4 with $\mathrm{C} 1$ (0.429 $\mathrm{mg}^{-1}$ of fresh matter). However, all substrates tested presented lower values than those found by Bulgari et al. (2017) for microgreens of Ocimum basilicum L. (0.815 $\mathrm{mg} \mathrm{g}^{-1}$ of fresh matter) and Beta vulgaris L. subsp. vulgaris $\left(0.771 \mathrm{mg} \mathrm{g}^{-1}\right.$ of fresh matter).

Plants treated with the substrate S2 presented a decreasing total chlorophyll contents as the EC of the nutritive solution was increased, presenting 0.439 (C1), 0.413 (C2), and 0.399 (C3) $\mathrm{mg} \mathrm{g}^{-1}$ of fresh matter (Figure 2). 

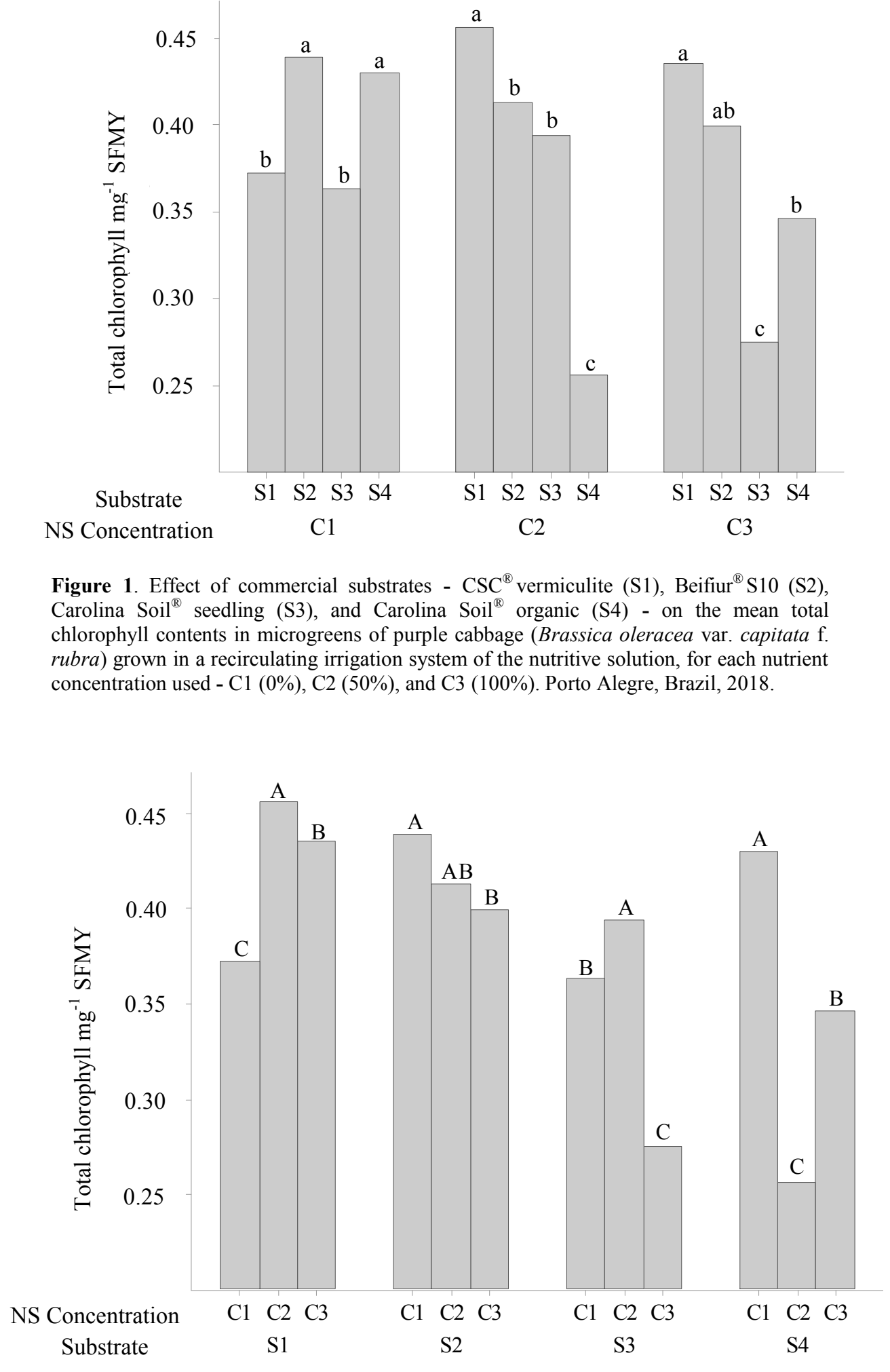

Figure 2. Effect of nutrient concentrations in the nutritive solution - $\mathrm{C} 1(0 \%), \mathrm{C} 2(50 \%)$, and $\mathrm{C} 3$ $(100 \%)$ - on the mean total chlorophyll contents in microgreens of purple cabbage (Brassica oleracea var. capitata f. rubra) grown in a recirculating irrigation system of the nutritive solution, for each commercial substrate used - $\operatorname{CSC}^{\circledR}$ vermiculite (S1), Beifiur ${ }^{\circledR}$ S10 (S2), Carolina Soil ${ }^{\circledR}$ seedling (S3), and Carolina Soil ${ }^{\circledR}$ organic (S4). Porto Alegre, Brazil, 2018. 
SFMY and SDMY increased as the nutrient concentration was increased, but the total chlorophyll contents did not follow this increase because not only the nutrient availability but other factors can affect its accumulation, such as salinity, oxygenation, temperature, and $\mathrm{pH}$ of the nutritive solution, light intensity, and air temperature and humidity. An inadequate condition of one of these factors can affect the chlorophyll accumulation (MARENCO; JESUS, 2008).
The evaluation of total carotenoid contents showed no differences between substrates in $\mathrm{C} 1$, presenting mean of $0.096 \mathrm{mg} \mathrm{g}^{-1}$ of fresh matter (Figure 3). The substrates S2 and S3 presented 38\% higher mean total carotenoid contents using $\mathrm{C} 2$ when compared to the substrates S1 and S4. This trend between the substrates was maintained when using C3, with S1 and S2 presenting higher total carotenoid contents than S3 and S4.

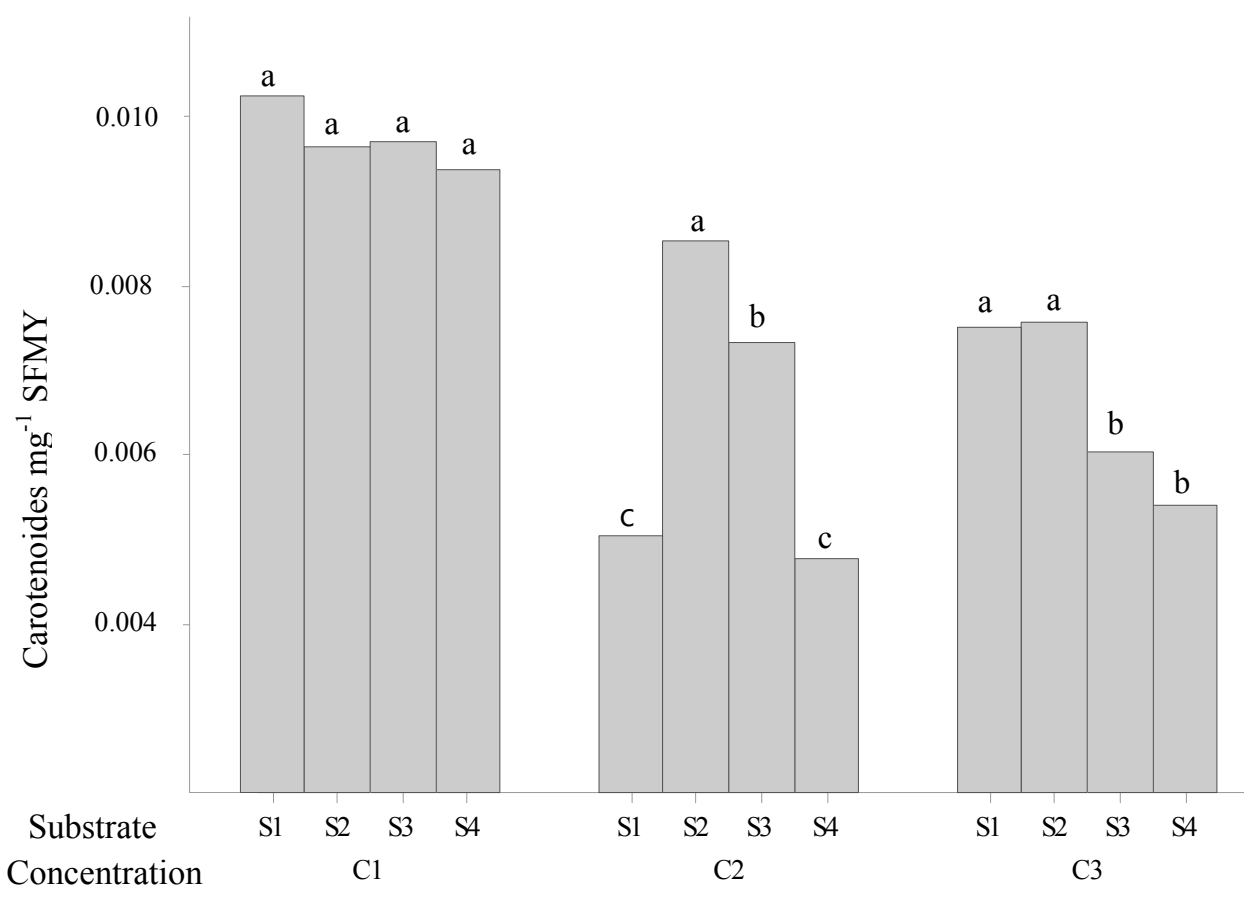

Figure 3. Effect of commercial substrates - $\mathrm{CSC}^{\circledR}$ vermiculite (S1), Beifiur ${ }^{\circledR} \mathrm{S} 10$ (S2), Carolina Soil ${ }^{\circledR}$ seedling (S3), and Carolina Soil ${ }^{\circledR}$ organic (S4) - on the mean total carotenoid contents in microgreens of purple cabbage (Brassica oleracea var. capitata f. rubra) grown in a recirculating irrigation system of the nutritive solution, for each nutrient concentration used - $\mathrm{C} 1(0 \%), \mathrm{C} 2(50 \%)$, and $\mathrm{C} 3(100 \%)$. Porto Alegre, Brazil, 2018.

The total carotenoid contents in the purple cabbage microgreens decreased as the nutrient concentrations in the nutritive solution was increased, for all substrates (Figure 4). The total carotenoid contents were $50 \%, 24 \%$, and $49 \%$ lower when using $\mathrm{C} 2$ for the substrates S1, S3, and S4, respectively, compared to $\mathrm{C} 1$. However, the total carotenoid contents were similar for these substrates in $\mathrm{C} 3$ and $\mathrm{C} 2$. The increase in nutrient concentration in the nutritive solution from $\mathrm{C} 1(0 \%)$ to $\mathrm{C} 2(50 \%)$ had no effect on the total carotenoid contents when using the substrate $\mathrm{S} 2$; however, they differed significantly from $\mathrm{C} 1(0 \%)$ to $\mathrm{C} 3(100 \%)$, presenting a decrease of $25 \%$.
The total carotenoid contents found were lower than those found by Samuolienè et al. (2017) 0.09 to $0.25 \mathrm{mg} \mathrm{g}^{-1}$ of fresh matter-when testing different light supply for the production of microgreens of Brassica juncea L., Beta vulgaris L., and Petroselinum crispum Mill., using peat as substrate, in a controlled environment with air temperatures of 17 to $21{ }^{\circ} \mathrm{C}$, photoperiod of 16 hours, and air relative humidity of 50 to $60 \%$. The purple cabbage microgreens in the present study were grown under mean temperature of $22.1{ }^{\circ} \mathrm{C}$, relative humidity of $74 \%$, and photoperiod of 13 hours inside the protected environment (means of the experimental period). 


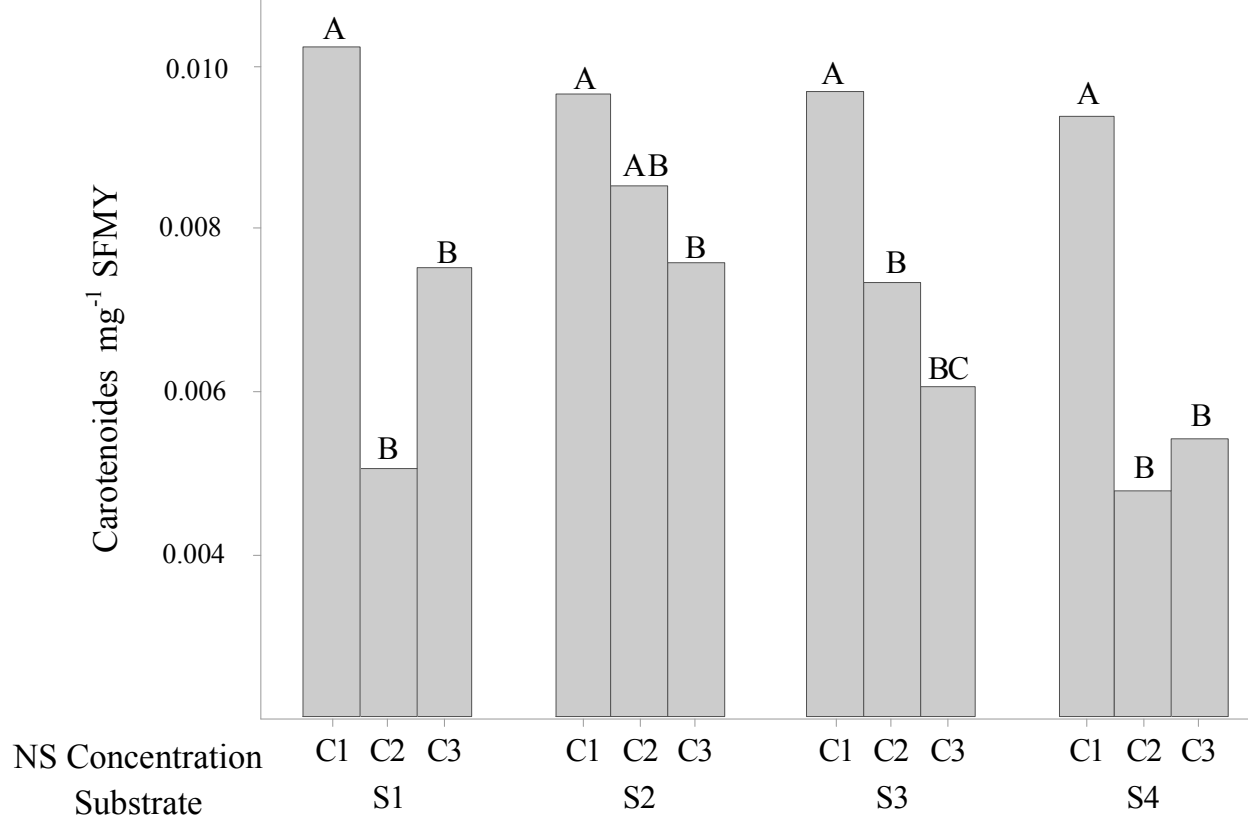

Figure 4. Effect of nutrient concentrations in the nutritive solution - $\mathrm{C} 1(0 \%), \mathrm{C} 2(50 \%)$, and C3 $(100 \%)$ - on the total carotenoid contents in microgreens of purple cabbage (Brassica oleracea var. capitata $f$. rubra) grown in a recirculating irrigation system of the nutritive solution, for each commercial substrate tested - $\mathrm{CSC}^{\circledR}$ vermiculite (S1), Beifiur ${ }^{\circledR} \mathrm{S} 10$ (S2), Carolina Soil $^{\circledR}$ seedling (S3), and Carolina Soil ${ }^{\circledR}$ organic (S4). Porto Alegre, Brazil, 2018.

Brazaityte et al. (2015) evaluated the effect of different light specters and intensities, using LEDs (Light Emitting Diode) over microgreens of Brassica spp. (Brassica juncea L; Brassica rapa var. Chinensis; Brassica rapa var. Rosularis), and reported that a higher total carotenoid accumulation occurs under higher light intensity and it is dependent mainly on the species evaluated.

No additional light was used in the present study; the plants grew under natural light, which was attenuated by a physical barrier (plastic film) covering the protected environment.

Besides light and species, nutrient and water availabilities also affect carotenoid accumulation. High nutrient concentrations in the nutritive solution generate a low plant' metabolism. Thus, the response of plants treated with only water is a higher carotenoid concentration because of the adverse conditions (KOPSELL; KOPSELL, 2010), as found in the present work.

However, the growth, harvest, and postharvest handling conditions can significantly affect the synthesis and degradation of phytonutrients, including vitamins and carotenoids. Therefore, further studies evaluating the effect of these practices on phytonutrients contents are needed.

\section{CONCLUSION}

The shoot fresh and dry matter yields and shoot height at harvest of purple cabbage microgreens are not affected by the different commercial substrates tested. The addition of nutrients to the nutritive solution increases the values of these variables, and the $100 \%$ nutrient concentration in the nutritive solution is the most indicated. The addition of $100 \%$ of nutrients to the nutritive solution in the substrates $\operatorname{CSC}^{\circledR}$ vermiculite and S10 Beifiur ${ }^{\circledR}$ generates a reduction of two days in the production cycle of purple cabbage microgreens. The substrates Carolina Soil ${ }^{\circledR}$ seedlings and Carolina Soil ${ }^{\circledR}$ organic do not require the addition of nutrients to the nutritive solution to decrease the production cycle of purple cabbage microgreens. The total soluble solids and total carotenoid contents decrease as the nutrient concentration in the nutritive solution is increased. The total chlorophyll content of purple cabbage microgreens varies according to the substrates used within the different nutrient concentrations in the nutritive solution.

\section{REFERENCES}

ARNON, D. I. Copper enzymes in isolated chloroplasts. Polyphenoloxidase in Beta vulgaris. Plant Physiology, v. 24, n. 1, p. 1, 1949.

BRAZAITYTÉ, A. et al. The effects of LED illumination spectra and intensity on carotenoid 
content in Brassicaceae microgreens. Food chemistry, v. 173, s/n., p. 600-606, 2015.

BULGARI, R. et al. Yield and quality of basil, Swiss chard, and rocket microgreens grown in a hydroponic system. New Zealand Journal of Crop and Horticultural Science, v. 45, n. 2, p. 119-129, 2017.

CAVINS, T. J. et al. Monitoring and managing $\mathrm{pH}$ and EC using the Pour Thru extraction method. Horticulture Information Leaflet, v. 590, s/n., p. 1$17,2000$.

BOODT, M. A. V. O.; VERDONCK, O. The physical properties of the substrates in horticulture. In: III SYMPOSIUM ON PEAT IN HORTICULTURE 26, 1971, Dublin. Proceedings... v. 26, p. 37-44.

FERREIRA, D. F. Sisvar: a computer statistical analysis system. Ciência e Agrotecnologia, v. 35, n. 6, p. 1039-1042, 2011.

FERREIRA, R. R. M. et al. Efeitos de sistemas de manejo de pastagens nas propriedades físicas do solo. Semina: Ciências Agrárias, v. 31, n. 4, p. 913 932, 2010.

GRUSZYNSKI， C. Resíduo agro-industrial "Casca de Tungue" como componente de substrato para plantas. 2002. 99 f. 2002. (Doutorado em Fitotecnia: Área de concentração em produção Vegetal) Universidade Federal do Rio Grande do Sul, Porto Alegre, 2011.

JANOVSKÁ, D.; STOCKOVÁ, L.; STEHNO, Z. Evaluation of buckwheat sprouts as microgreens. Acta Agriculturae Slovenica, v. 95, n. 2, p. 157, 2010.

KÄMPF, A. N. Produção comercial de plantas ornamentais. 2 ed. Guaíba, RS: Agrolivros, 2005. $254 \mathrm{p}$.

KÄMPF, A. N.; FERMINO, M. H. Substratos para plantas: a base da produção vegetal em recipientes. In: ENCONTRO NACIONAL SOBRE SUBSTRATOS PARA PLANTAS, 2000, Porto Alegre. Anais... Porto Alegre: GÊNESIS. 2000. p. 112-121

KLEIN, C. et al. Caracterização química e física de substratos para a produção de mudas de alface. Agropecuária Gaúcha, v. 18, n. 2, p. 110, 2012.

KOPSELL, D. A. et al. Shoot tissue pigment levels increase in 'Florida Broadleaf'mustard (Brassica juncea L.) microgreens following high light treatment. Scientia Horticulturae, v. 140, n. 1, p. 96
$-99,2012$.

KOPSELL, D. A.; KOPSELL, D. E. Fruits and Vegetables. In: WATSON, R. R; PREEDY, V. R. (Eds.). Bioactive Foods in Promoting Health: Fruits and Vegetables. San Diego: Academic Press, 2010. v.1, cap. 6, p 645-662.

LICHTENTHALER, H. K. Chlorophylls and carotenoids: pigments of photosynthetic biomembranes. In: Methods in enzymology. Cambridge: Academic Press, 1987, v. 148, p. 350382.

MACIEL, G. M. et al. Influência da época de colheita no teor de sólidos solúveis em frutos de minitomate. Scientia Plena, v. 11 , n. 12, p. 1-6, 2015.

MARENCO, R. A.; JESUS, S. V. de. O SPAD-502 como alternativa para a determinação dos teores de clorofila em espécies frutíferas. Acta Amazonica, v. 38 , n. 4, p. 815-818, 2008

SAMUOLIENĖ, G. et al. Blue light dosage effects carotenoids and tocopherols in microgreens. Food chemistry, v. 228, s/n., p. 50-56, 2017.

SAMUOLIENĖ, G. et al. Red light-dose or wavelength-dependent photoresponse of antioxidants in herb microgreens. PloS one, v. 11, n. 9, p. $\mathrm{e} 0163405,2016$.

SANTOS, O. S. et al. Produção de forragem hidropônica de cevada e milho e seu uso na alimentação de cordeiros. 1. ed. Santa Maria, RS: UFSM/CCR, 2004. (Informe Técnico).

SCHÄFER, GILMAR; SOUZA, PVD de; FIOR, CLAUDIMAR SIDNEI. Um panorama das propriedades físicas e químicas de substratos utilizados em horticultura no sul do Brasil. Ornamental Horticulture, v. 21, n. 3, p. 299-306, 2015.

SIRTAUTAS, R. et al. The impact of supplementary short-term red LED lighting on the antioxidant properties of microgreens. In: VII INTERNATIONAL SYMPOSIUM ON LIGHT IN HORTICULTURAL SYSTEMS, 2012, Wagening. v. 956 , p. $649-656$.

SOARES, C. D. F. et al. Processamento mínimo de espinafre Nova Zelândia. Revista Iberoamericana de Tecnología Postcosecha, v. 17, n. 2, p. 296-306, 2016.

SOBREIRA, F. M. et al. Taste quality of salad and cherry tomatoes and their relationship with the morphoagronomic characteristics of the fruits. 
Ciência e Agrotecnologia, v. 34, n. 4, p. 1015-1023, 2010.

XIAO, Zhenlei et al. Microgreens of Brassicaceae: Mineral composition and content of 30 varieties. Journal of Food Composition and Analysis, v. 49, n. 31, p. 87-93, 2016. 